\title{
Organizational trust, employee commitment and job satisfaction in Turkish hospitals: implications for public policy and health
}

Ömer Gider, ${ }^{1}$ Mesut Akdere ${ }^{2}$ and Mehmet Top ${ }^{3}$

${ }^{1}$ Department of Healthcare Management, School of Health, Muğla Sitkı Koçman University, Muğla, Turkey. ${ }^{2}$ Department of Technology Leadership \& Innovation, Purdue University, West Lafayette, Indiana, United States of America (Correspondence to: Mesut Akdere: makdere@purdue.edu). ${ }^{3}$ Department of Healthcare Management, Faculty of Economics and Administrative Sciences, Hacettepe University, Ankara, Turkey.

\begin{abstract}
Background: Understanding relationships between factors that can affect organizational outcomes such as organizational trust, employee commitment and job satisfaction is important to foster healthy work conditions in organizations.

Aims: This study aimed to determine the perception of Turkish physicians about organizational trust, employee commitment and job satisfaction and determine the relationships between them.

Methods: A questionnaire was developed based on three standard survey instruments and given to 1679 doctors in four training and research hospitals in Istanbul, Turkey, in 2013. The Pearson correlation coefficient was calculated and regression analyses were conducted.
\end{abstract}

Results: A total of 304 doctors completed the survey (18.1\% response rate). Most were males $(57 \%)$, over 30 years old (62\%) and specialists ( $82 \%)$. A strong positive correlation was found among the study variables $(P \leq 0.001)$. Regression analyses indicated that organizational trust was a significant predictor of job satisfaction and commitment.

Conclusions: Policy-makers need to consider implementing interventions in the health care system to improve the working conditions of current and future doctors in Turkey, in order to attract and retain them and prevent health care labour force losses.

Keywords: Quality of life, SF-36, Tunisia, HRQOL, population

Citation: Gider Ö; Akdere M; Top M. Organizational trust, employee commitment and job satisfaction in Turkish hospitals: implications for public policy and health. East Mediterr Health J. 2019;25(9):622-629 https://doi.org/10.26719/emhj.19.010

Received: 21/11/16; accepted: 01/10/17

Copyright (C) World Health Organization (WHO) 2019. Some rights reserved. This work is available under the CC BY-NC-SA 3.0 IGO license (https:// creativecommons.org/licenses/by-nc-sa/3.0/igo)

\section{Introduction}

Employee attitudes related to organizational trust, employee commitment, and job satisfaction have long been integral constructs for organizational behavior research as they are significantly embedded within the employee psyche $(1,2)$. Health care organizations are not different when it comes to employee psyche. These constructs are significant parts of the way employees get motivated, think critically, and achieve performance excellence. Furthermore, these constructs can help healthcare researchers assess and understand various organizational outcomes such as employee productivity, organizational effectiveness, quality of care delivered, patient safety and performance management (3). Specifically, increased levels of organizational trust, employee commitment, and job satisfaction positively affect organizational outcomes (4). As organizations are becoming more complex, these organizational constructs are increasingly vital for the success of health care professionals. A growing literature on health care in Turkey has begun to explore the impact and relationship of these constructs with various organizational outcomes $(5,6)$. In this article, we aim to contribute to the growing body of knowledge and identify issues that may present long-term implications for both policy and practice in a country with a large youth population.
Considering the fact that a large shortage exists in the physician labor force in the Turkish health care sector, there is further need to study potential relationships among various organizational dynamics in new physicians' work and job attitudes, since these relationships may predict physicians' decisions to remain in the profession and support reducing high turnover rates $(7,8)$. Consequently, this study aims to examine the relationship among various organizational variables and explore organizational dynamics that would impact, directly or indirectly, health care professionals' organizational trust and commitment as well as job satisfaction, which are critical for retention and turnover issues prevalent in the health care sector. Furthermore, the study provides recommendations for health care planning and management as well as health care policy.

\section{Review of literature}

This study focuses on work attitudes of organizational trust, commitment, and job satisfaction to examine potential relationships among these organizational outcomes. Furthermore, the study discusses implications of factors on physicians' work environment and career progress in four major Turkish hospitals. Such an empirical study provides a further understanding of the varying levels of association among organizational dynamics and their impact on fostering a supportive organizational 
culture, which, in turn, will help increase levels of trust, commitment, and job satisfaction among physicians.

Organizational trust (OT) is the belief of an individual or a group that the organization will make every effort, whether explicit or implied, to act in accordance with their commitments (9). Thus, trust serves as one of the instruments in facilitating organizational relationships both among its members and between the organization and its members. Organizational commitment (OC) influences and impacts members' attitudes and perceptions of their jobs and careers. Simply defined, $O C$ is "a perceived bond between the individual and the organization" (10). It is comprised of three distinct components: affective, continuance, and normative (11). Job satisfaction "is an attitude that reflects the extent to which an individual is gratified by or fulfilled in his or her work" (12). JS is an important indicator for organizational success. Specifically, in today's "challenging economic times, it may be tempting to focus solely on the bottom line and forget the importance of motivating employees" (13). However, this may be costlier to the organization's bottom line as decreased levels of job satisfaction may result in decreased levels of employee performance and productivity as well as customer satisfaction (14). Additionally, in health care, job satisfaction is integral to quality improvement (15).

\section{Purpose and hypotheses}

Following the review of the existing literature and factors involved in employee commitment, organizational trust, and job satisfaction, this section discusses the research methodology used in the study. This study examines the relationships among three important job attitudes held by a sample of physicians at four training and research hospitals in Istanbul, Turkey. The study findings help health care administrators and policy-makers comprehend relevant issues associated with physician training starting with the physician residency and develop policies to increase the levels of trust, commitment, and satisfaction among physicians in order to attract and retain a shrinking workforce of physicians in the face of rapidly growing labour force need for physicians. The following hypotheses are tested in this study:

- H1: There are significant relationships between the perceived levels of trust, commitment, and the job satisfaction of physicians.

- H2: Physicians' levels of trust and commitment affect their levels of job satisfaction.

- H3: Physicians' levels of trust and job satisfaction affect their levels of commitment.

\section{Methods}

\section{Instruments}

We used three instruments to measure physicians' perceptions on organizational trust, commitment, and job satisfaction in this study. These include the Organiza- tional Trust Inventory short form (OTI) -12 items measuring employee trust for their supervisors and the organization (9), the Employee Commitment Scales (ECS)-24 items, each set of 8 items measuring one of the three dimensions of employee commitment (16), and the Job Satisfaction Survey (JSS) - designed for service-type jobs, which consists of 36 items measuring an overall satisfaction score for each participant as well as other important aspects (pay, promotion, supervision, fringe benefits, contingent rewards, operating procedures, co-workers, nature of work, communication) of job satisfaction specific to each participant (17). The OTI consisted of 12 quantitative items in statement form with 8 of the items measuring employee trust with respect to their supervisors and the remaining 4 items measuring employee trust with respect to the entire organization (9). The responses were measured using a 7-point likert-scale in which 1 implied strong disagreement while 7 indicated a strong agreement with the associated item. Similarly, we used the ECS to measure OC. The ECS included a total of 24 items using a 7-point likert-scale similar to the OTI. Finally, we computed scores for organizational commitment subscales for each participant. The JSS (17) measured employee job satisfaction and is designed for health care-related professions. Furthermore, JSS provides an overall satisfaction score for study participants and also measures other related aspects of job satisfaction specific to each individual. The JSS contains 36 quantitative items in statement form, using a 7-point likert scale.

The study questionnaire, which included the three aforementioned instruments, was rigorously translated from English to Turkish. Furthermore, a pilot study was conducted to test whether the translated scales were easy to comprehend by the sample population. A convenience sample of 30 physicians was asked to complete the questionnaire and provide feedback on each translated item. Upon completion of the pilot study, a final version of the questionnaire was produced. The Cronbach alpha coefficient scores for each instrument for reliability purposes in this study are as follows: the OTI: 0.92; the affective commitment: 0.87 ; the continuance commitment: 0.81 ; the normative commitment: 0.79 ; and the JSS: 0.89 .

\section{Data collection}

This study was conducted at four major training and research hospitals in Istanbul, Turkey. The inclusion criteria included: being a large teaching and research hospital (with beds above 500) and being located in a metropolitan neighbourhood, since the workplace environment in these high demand intensive hospitals are closely related to the constructs of the study, as it highlights specific challenges physicians may face in urban settings as compared to the ones working in rural areas. Using a convenience sampling method, the questionnaire was distributed in hard copy with a return envelope included to all 1679 physicians working in these hospitals; 304 physicians (18.1\% response rate) returned the completed surveys. An informed consent form was attached to the survey to provide further information about the study to the participants. Follow-up emails and hospital-level physician communication plat- 
forms were used to increase response rate.

Descriptive statistics of the participants were computed; $57 \%$ of the participants were male while $43 \%$ were female, and $18 \%$ were general practitioners while $82 \%$ were specialists; $55 \%$ worked in clinics while $36 \%$ worked in polyclinics; and 9\% worked in other hospital units such as operating rooms, intensive care, nuclear medicine, and radiology. In terms of number of years at the current position, $26 \%$ have been working for over 11 years, $24 \%$ for $6-10$ years, $36 \%$ for $2-5$ years, and $14 \%$ for under a year. $18 \%$ were over 41 years and older while $44 \%$ were in the ages of $31-40$, and $38 \%$ were $25-30$ years of age.

Scores for the employee commitment, organizational trust, and job satisfaction were calculated, and Cronbach's alphas were measured for reliability purposes. Pearson correlation was obtained to analyse correlations among trust, commitment, and job satisfaction, testing H1. Multiple regression analyses were conducted to analyse whether or not physicians' levels of trust and commitment affect their levels of job satisfaction, testing H2. Lastly, the effect of physicians' levels of trust and job satisfaction on their levels of commitment was examined, thus testing $\mathrm{H}_{3}$.

\section{Ethical considerations}

The study was approved by the Institutional Review Board of Istanbul Provincial Office of Health. No personal identifier information was collected from the participants.

\section{Results}

This study used quantitative methods for collecting data from physicians in Turkish hospitals; 304 physicians from the sample population completed the questionnaire, comprising about $18 \%$ of all the questionnaires sent out to study Turkish physicians' trust, commitment, and job satisfaction in four large training and research hospitals. We first identified the demographics such as age, sex, and health care unit/clinic. We then tested our three study hypotheses. Descriptive statistics were calculated for all continuously scaled variables such as trust (the OTI), commitment (the ECS), and job satisfaction (the JSS). The organizational trust mean score was 3.85 (SD = 0.99), and the employee commitment scales had a mean score for affective, continuance, and normative commitment, respectively, of 3.88, 3.92, and $3.79(\mathrm{SD}=0.68$; $0.73 ; 0.75$ ). The job satisfaction mean score was 4.08 (SD $=0.37$ ). Table 1 presents the results of the ANOVA test in terms of mean scores and standard deviations computed for trust, commitment, and job satisfaction organized by the hospitals where this study was conducted.

Table 3 illustrates the organizational commitment, organizational trust, and job satisfaction levels of the participants. As these scores get closer to 7, they indicate a very high level of the associated organizational dynamic. Similarly, as the scores get closer to 1 , they indicate the lowest level of those organizational dynamics. As such, organizational dynamics of the participants reported in this study remain as average (OC average is 3.87 , and the highest OC dimension being 3.92). In addition, JS has a higher average as compared to OC and OT. Table 3 also illustrates standard deviation, minimum and maximum values, and range for OT, OC, and JS. It is important to note that both range and standard deviation are significantly low for JS. In similar studies conducted in Europe, JS levels of participant physicians were reported to be much higher. For example, Rosta et al. (18) conducted a comparative study on JS among 1427 German physicians and 478 Norwegian physicians, and reported that the German physicians have 4.55 while the Norwegian physicians reported to have 5.09 mean score. Mean scores of affective commitment, continuance commitment, normative commitment, and overall employee commitment are significantly different in terms of the hospitals. The mean scores of three types of employee commitment dimensions and overall employee commitment at the fourth hospital are higher than other hospitals. Furthermore, there is significant variability among hospitals in terms of physicians' organizational trust and job satisfaction.

In $\mathrm{H} 1$, we tested whether any relationships exist among the perceived levels of trust, commitment, and job satisfaction of physicians using a two-tailed Pearson's correlation. Table 2 illustrates the correlation among trust, commitment, and job satisfaction of physicians, as well as significance of correlation coefficients. As indicated in Table 2, there are significant relationships among trust, commitment, and job satisfaction. Scores for trust and commitment yielded a significantly higher correlation $(r=0.348, P<0.001)$, as compared to correlation scores that of between commitment and job satisfaction. In addition, the Pearson correlation indicated a statistically significant positive correlation between the trust and job satisfaction scores $(r=0.184, P=0.001)$. Furthermore, there are statistically significant positive correlations among three dimensions of commitment and trust when compared to correlations among three dimensions of commitment and job satisfaction in this study. In general, there are statistically significant positive correlations among trust, commitment, and job satisfaction scores of physicians. In Table 2, most of the correlation coefficients differed from zero, empirically supporting the relevance of the purpose of this research to study relationships among these variables. Thus, H1 [there are relationships among the perceived levels of trust and commitment and the job satisfaction of physicians] was supported.

We performed multiple regression analyses using trust and three dimensions of commitment as independent variables and job satisfaction as a dependent variable. Table 3 displays that independent variables account for approximately $26 \%$ of the total variance in job satisfaction $\left(R^{2}=0.265, F=18.402, P<0.001\right)$.

The Durbin-Watson statistic was $1.88(<2.50)$, which did not reveal autocorrelation for regression model, confirming the suitability of using regression for analysis. Furthermore, variance inflation factors (VIFs) were all below 10 (from 1.11 to 1.32), indicating the absence of multicollinearity (19). A multiple regression analysis (adjusted $\mathrm{R}^{2}=0.25 ; \mathrm{P}<0.001$ ) produced two significant predictors of job satisfaction: continuance commitment $(t=2.979, P=0.035)$ and organizational trust $(t=6.641, P$ 


\begin{tabular}{|c|c|c|c|c|c|}
\hline Variable & Hospital & No. & Mean (SD) & $\boldsymbol{F}$ & P-value \\
\hline \multirow{5}{*}{ Trust } & Hospital I & 43 & $3.85(0.99)$ & \multirow{5}{*}{0.901} & \multirow{5}{*}{0.441} \\
\hline & Hospital II & 162 & $3.91(0.64)$ & & \\
\hline & Hospital III & 48 & $3.73(0.95)$ & & \\
\hline & Hospital IV & 51 & $3.76(0.73)$ & & \\
\hline & Total & 304 & $3.85(0.77)$ & & \\
\hline \multirow{5}{*}{ Affective commitment } & Hospital I & 43 & $3.90(0.68)$ & \multirow{5}{*}{3.84} & \multirow{5}{*}{0.01} \\
\hline & Hospital II & 162 & $3.98(0.58)$ & & \\
\hline & Hospital III & 48 & $3.61(0.85)$ & & \\
\hline & Hospital IV & 51 & $3.81(0.74)$ & & \\
\hline & Total & 304 & $3.88(0.68)$ & & \\
\hline \multirow{5}{*}{ Continuance commitment } & Hospital I & 43 & $3.95(0.68)$ & \multirow{5}{*}{6.74} & \multirow{5}{*}{0.001} \\
\hline & Hospital II & 162 & $4.03(0.58)$ & & \\
\hline & Hospital III & 48 & $3.51(0.85)$ & & \\
\hline & Hospital IV & 51 & $3.93(0.74)$ & & \\
\hline & Total & 304 & $3.92(0.73)$ & & \\
\hline \multirow{5}{*}{ Normative commitment } & Hospital I & 43 & $3.85(0.79)$ & \multirow{5}{*}{6.66} & \multirow{5}{*}{0.001} \\
\hline & Hospital II & 162 & $3.86(0.61)$ & & \\
\hline & Hospital III & 48 & $3.36(0.83)$ & & \\
\hline & Hospital IV & 51 & $3.92(0.92)$ & & \\
\hline & Total & 304 & $3.79(0.75)$ & & \\
\hline \multirow{5}{*}{ Overall employee commitment } & Hospital I & 43 & $3.90(0.50)$ & \multirow{5}{*}{10.85} & \multirow{5}{*}{0.001} \\
\hline & Hospital II & 162 & $3.96(0.42)$ & & \\
\hline & Hospital III & 48 & $3.49(0.62)$ & & \\
\hline & Hospital IV & 51 & $3.89(0.58)$ & & \\
\hline & Total & 304 & $3.87(0.52)$ & & \\
\hline \multirow{5}{*}{ Job satisfaction } & Hospital I & 43 & $4.15(0.48$ & \multirow{5}{*}{1.55} & \multirow{5}{*}{0.200} \\
\hline & Hospital II & 162 & $4.09(0.28)$ & & \\
\hline & Hospital III & 48 & $4.07(0.48)$ & & \\
\hline & Hospital IV & 51 & $3.99(0.37)$ & & \\
\hline & Total & 304 & $4.08(0.37)$ & & \\
\hline
\end{tabular}

SD = standard deviation.

\begin{tabular}{|c|c|c|c|c|c|c|c|}
\hline Variable & $\begin{array}{l}\text { Statistical } \\
\text { values }\end{array}$ & $\begin{array}{c}\text { Affective } \\
\text { commitment }\end{array}$ & $\begin{array}{l}\text { Continuance } \\
\text { commitment }\end{array}$ & $\begin{array}{l}\text { Normative } \\
\text { commitment }\end{array}$ & $\begin{array}{c}\text { Overall } \\
\text { employee } \\
\text { commitment }\end{array}$ & $\begin{array}{c}\text { Organizational } \\
\text { trust }\end{array}$ & $\begin{array}{c}\text { Job } \\
\text { satisfaction }\end{array}$ \\
\hline \multirow{2}{*}{$\begin{array}{l}\text { Affective } \\
\text { commitment }\end{array}$} & $r$ & 1 & & & & & \\
\hline & $P$ & & & & & & \\
\hline \multirow{2}{*}{$\begin{array}{l}\text { Continuance } \\
\text { commitment }\end{array}$} & $r$ & $0.175^{a}$ & 1 & & & & \\
\hline & $P$ & 0.002 & & & & & \\
\hline \multirow{2}{*}{$\begin{array}{l}\text { Normative } \\
\text { commitment }\end{array}$} & $r$ & $0.337^{\mathrm{a}}$ & $0.328^{a}$ & 1 & & & \\
\hline & $P$ & $<0.001$ & $<0.001$ & & & & \\
\hline \multirow{2}{*}{$\begin{array}{l}\text { Overall employee } \\
\text { commitment }\end{array}$} & $r$ & $0.680^{a}$ & $0.701^{a}$ & $0.781^{a}$ & 1 & & \\
\hline & $P$ & $<0.001$ & $<0.001$ & $<0.001$ & & & \\
\hline \multirow{2}{*}{$\begin{array}{l}\text { Organizational } \\
\text { trust }\end{array}$} & $r$ & $0.253^{\mathrm{a}}$ & $0.173^{\mathrm{a}}$ & $0.328^{a}$ & $0.348^{a}$ & 1 & \\
\hline & $P$ & $<0.0001$ & 0.003 & $<0.0001$ & $<0.001$ & & \\
\hline \multirow{2}{*}{ Job satisfaction } & $r$ & $0.140^{b}$ & $0.119^{b}$ & $0.141^{\mathrm{b}}$ & $0.184^{a}$ & $0.400^{\mathrm{a}}$ & 1 \\
\hline & $P$ & 0.016 & 0.041 & 0.015 & 0.001 & $<0.001$ & \\
\hline
\end{tabular}

$r=$ Pearson correlation coefficient.

${ }^{a}$ Correlation significant at $P=0.01$ level (two-tailed).

${ }^{b}$ Correlation significant at $P=0.05$ level (two-tailed). 


\begin{tabular}{|c|c|c|c|c|c|c|c|c|c|c|c|}
\hline Predictor & $\begin{array}{c}\text { Unstandardized } \\
\text { beta }\end{array}$ & SE & $\begin{array}{c}\text { Standardized } \\
\text { beta }\end{array}$ & $t$ & $\mathbf{P}$ & VIF & $\mathbf{R}$ & $\mathbf{R}^{2}$ & $\boldsymbol{F}$ & $P$ & $\begin{array}{l}\text { Durbin- } \\
\text { Watson }\end{array}$ \\
\hline Constant & 3.194 & 0.160 & - & 19.979 & 0.001 & & 0.486 & 0.265 & 18.402 & 0.001 & 1.887 \\
\hline $\begin{array}{l}\text { Affective } \\
\text { commitment }\end{array}$ & 0.018 & 0.031 & 0.032 & 0.556 & 0.579 & 1.182 & & & & & \\
\hline $\begin{array}{l}\text { Continuance } \\
\text { commitment }\end{array}$ & 0.128 & 0.029 & 0.255 & 2.979 & 0.035 & 1.119 & & & & & \\
\hline $\begin{array}{l}\text { Normative } \\
\text { commitment }\end{array}$ & 0.002 & 0.031 & 0.005 & 0.074 & 0.941 & 1.329 & & & & & \\
\hline Trust & 0.183 & 0.028 & 0.381 & 6.641 & 0.001 & 1.153 & & & & & \\
\hline
\end{tabular}

SE = standard error, VIF = variance inflation factors.

= 0.001). However, affective commitment and normative commitment were not statistically significant predictors of job satisfaction in this study. Thus, $\mathrm{H}_{2}$ [physicians' levels of trust and commitment (affective commitment, continuance commitment, normative commitment) affect their levels of job satisfaction] was partially supported for trust and continuance commitment.

To test $\mathrm{H}_{3}$, we conducted a multiple regression analysis using commitment as dependent variable and trust and job satisfaction as independent variables. Table 4 illustrates that independent variables account for approximately $12 \%$ of the total variance in employee commitment $\left(R^{2}=0.123, F=20.630, P<0.001\right)$. The Durbin-Watson statistic was 1.70 (>2.50), which did not reveal autocorrelation among residuals, confirming the suitability of using regression for analysis. Furthermore, variance inflation factors (VIFs) were all below 10 (1.17 and 1.19), indicating the absence of multicollinearity (19). A multiple regression analysis (adjusted $R^{2}=0.12, P<0.001$ ) produced one significant predictor of commitment: trust $(t=5.328, P=0.001)$. Job satisfaction was not a statistically significant predictor of employee commitment in this study. The results are summarized in Table 4.

Thus, $\mathrm{H}_{3}$ (physicians 'levels of trust and job satisfaction affect their overall levels of comm itment) was supported for trust but not for job satisfaction.

\section{Conclusion and directions for future studies}

In this study, we investigated various aspects of trust, commitment, and job satisfaction of Turkish physicians. The average trust level was 3.85 , and the average commit- ment level was found to be 3.87 , while the average job satisfaction level was 4.08. There were statistically significant relationships among trust, commitment, and job satisfaction of physicians at four training and research hospitals in Istanbul, Turkey. We found continuance commitment and trust to be significant predictors of job satisfaction, whereas trust was a significant predictor of commitment.

The findings of this study present several intervention opportunities for hospital administration as well as planning and policy-makers of health care in Turkey. Most importantly, hospital administrators in Turkey should make regular, organization-wide assessments of the nature and levels of trust, commitment, and job satisfaction of their employees and then design and develop programmes and activities to address these needs and improve the environment. Considering that their profession is in high-demand with low-social support, physicians unsurprisingly experience high levels of depression (20). It also is deemed crucial for hospital administrators to develop more specific and effective strategies to improve employee perceptions of the organization. Additionally, hospitals should consider evaluating and assessing managerial success based in part on their ability to build a community of staff that has high levels of trust, commitment, and job satisfaction to foster employee well-being $(21,22,23)$. This can be addressed through annual performance reviews, which incorporate 360-degree feedback. Finally, we believe that the findings of this study will encourage Turkish hospital administrators to concentrate on building positive interdepartmental relations and interdisciplinary respect within the hospital. Hospital organizational charts need to be revised to reflect a shift from functioning in silos to removing

\begin{tabular}{|c|c|c|c|c|c|c|c|c|c|c|c|}
\hline Predictor & $\begin{array}{c}\text { Unstandardized } \\
\text { beta }\end{array}$ & SE & $\begin{array}{c}\text { Standardized } \\
\text { beta }\end{array}$ & $t$ & $\mathbf{P}$ & VIF & $\mathbf{R}$ & $\mathbf{R}^{2}$ & $\boldsymbol{F}$ & $\boldsymbol{P}$ & $\begin{array}{l}\text { Durbin- } \\
\text { Watson }\end{array}$ \\
\hline Constant & 2.649 & 0.315 & & 8.418 & 0.001 & & 0.351 & 0.123 & 20.630 & 0.001 & 1.707 \\
\hline Trust & 0.214 & 0.043 & 0.318 & 5.328 & 0.001 & 1.172 & & & & & \\
\hline Job satisfaction & 0.097 & 0.084 & 0.069 & 1.156 & 0.249 & 1.194 & & & & & \\
\hline
\end{tabular}


institutional barriers for more interdepartmental job functions. The existing literature support these ideas and indicate that increased levels of trust, commitment, and job satisfaction will significantly improve overall organizational performance $(24,25,26,27)$, and the ability to apply knowledge onto organizational processes is critical for promotion of health in hospitals (28).

The limitations of this study are related to the cross sectional design, low response rate, and its inability to support strong claims of causality. The potential for response bias as a result of using self-report questionnaires also must be taken into consideration (29). Furthermore, the present study focused on physicians in Turkey. Conducting a large-scale study of this topic involving all Turkish health care professionals might provide significant results for effective health care administration and policy-making.

The results of this study support the argument for better management of the health care workforce in Turkey to attract and retain these highly skilled professionals.
While hospital administrators widely face financial challenges in increasing quality of care on a continuous basis, (30), organizational issues such as high-power distance leadership (generally results in coercion) $(31,32)$, work-life balance issues, heavy workload and unsupportive organizational culture (33) need further addressing as part of the governmental health planning and management. Such issues may present barriers impacting the organizational dynamics discussed in this study that prevent health care professionals from being highly committed and involved (34). The findings of the study further call for government-level intervention to organize and enhance work conditions in order to achieve work-life balance for physicians and all other health care professionals.

\section{Funding: None.}

Competing interests: None declared.

\section{Confiance organisationnelle, engagement du personnel et satisfaction au travail dans les hôpitaux turcs : implications en faveur des politiques publiques et de la santé}

\section{Résumé}

Contexte: Comprendre les relations entre les facteurs susceptibles d'avoir une incidence sur les résultats de l'organisation tels que la confiance organisationnelle, l'engagement du personnel et la satisfaction au travail est important pour favoriser des conditions de travail saines au sein des organisations.

Objectif: La présente étude visait à déterminer la perception des médecins turcs concernant la confiance organisationnelle, l'engagement du personnel et la satisfaction au travail et à déterminer les relations entre ces facteurs.

Méthodes : Un questionnaire a été mis au point sur la base de trois instruments d'enquête normalisés et remis aux 1679 médecins de quatre hôpitaux de formation et de recherche à Istanbul en 2013. Le coefficient de corrélation de Pearson a été calculé et des analyses de régression effectuées.

Résultats : Un total de 304 médecins a participé à cette enquête (taux de réponse de 18,1\%). La plupart étaient des hommes (57\%), âgés de plus de 30 ans $(62 \%)$ et des spécialistes ( $82 \%)$. On a observé une forte corrélation positive parmi les variables étudiées $(p \leq 0,001)$. Les analyses de régression indiquaient que la confiance organisationnelle constituait un facteur prédictif important de la satisfaction au travail et de l'engagement.

Conclusions : Les responsables de l'élaboration des politiques doivent envisager de mettre en œuvre des interventions dans le système de santé afin d'améliorer les conditions de travail des médecins actuellement en poste et de leurs futurs confrères dans l'objectif de les attirer et de les fidéliser et de prévenir la diminution des effectifs des personnels de santé.

$$
\begin{aligned}
& \text { الثقة التنيمية والتزام الموظفين والرضا الوظيفي في المستشفيات التركية: الآثار المترتبة على السياسة العامة والصحة } \\
& \text { عمر جيدر، مسعود أكدري، محمد توب الموني } \\
& \text { الخلاصة } \\
& \text { الخلفية: من المهم فهم العلاقات بين العوامل التي يمكن أن تؤثر على التتائج التنظيمية مثل الثقة التنظيمية والتزام الموظفين و الرضا الوظيفي لتعزيز } \\
& \text { ظروف العمل الصحية في المؤسسات. } \\
& \text { الأهداف: هدفت هذه الدراسة إلى تحديد تصور الأطباء الأتراك عن الثقة التنظيمية والتزام الموظفين والرضا الوظيفي الوظي، وتحديد ما يربط بينها من } \\
& \text { علاقات. }
\end{aligned}
$$

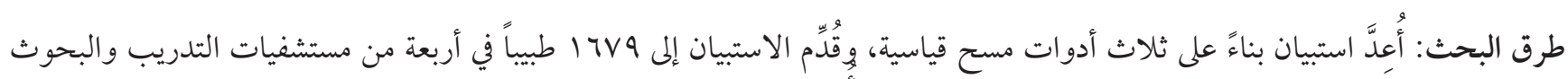

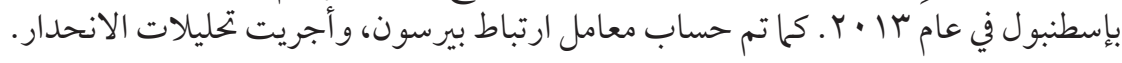

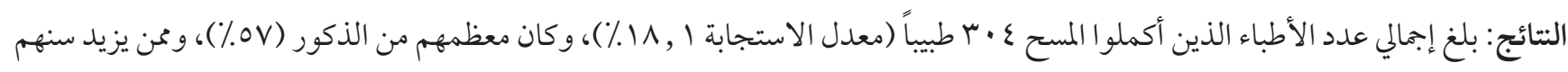




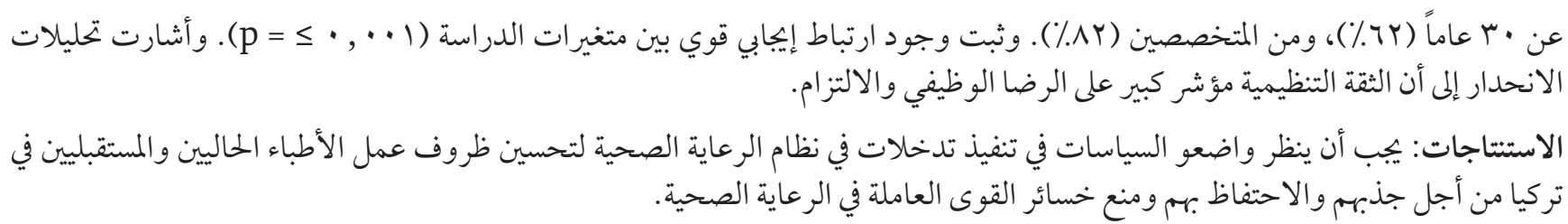

\section{References}

1. Thompson ER, Phua, FT. A brief index of affective job satisfaction. Group \& Organization Management. 2012; 37(3):275-307.

2. Wang G, Lee PD. Psychological empowerment and job satisfaction: An analysis of interactive effects. Group \& Organization Management. 2007; 34(3):271-296.

3. Hanson M, Miller A. The productive use of strengths: A shared responsibility. Industrial and Commercial Training. 2012; 34(1):95-100.

4. Carmeli A, Freund A. Work commitment, job satisfaction and job performance: An empirical investigation. Intl. J. of Org. Theory and Behavior. 2004; 7 (2):289-303.

5. Tanner BM. Analysis of the relationships among job satisfaction, organizational trust, and organizational commitment in an acute care hospital. (Unpublished doctoral dissertation). San Francisco: Faculty of Saybrook Graduate School and Research Center; 2007.

6. Durna U, Eren V. The examination of organisational commitment in connection with three components of commitment. Doğuş Üniversitesi Dergisi. 2005; 6(2):210-219. (in Turkish).

7. Top M, Akdere M, Tarcan M. Transformational leadership, job satisfaction, organizational commitment, organizational trust in Turkish public hospitals: Public servants versus private sector employees. International Journal of Human Resource Management. (2015);26(9):1259-1282.

8. Akdere M, Top M, Dikmetas E, Ergin G. An analysis of resident physician occupational burnout in Turkey: Implications for organizational culture. European Journal of Cross-Cultural Competence and Management. 2014;3(3/4):240-256.

9. Cummings L, Bromiley P. The organizational trust inventory (OTI). In R Kramer \& T Tyler (Eds.), Trust in organizations: Frontiers of theory and research. Thousand Oaks: Sage Publishers; 1996:302-330.

10. Vandenberghe C. Organizational commitment. In H J Klein, TE Becker, \& J P Meyer (Eds.), Commitment in organizations. New York: Routledge; 2009:100.

11. Meyer J, Allen N. A three-component conceptualization of organizational commitment. Human Resource Mgmt Review. 1991;1:61-89.

12. Griffin RW. Management. (11th ed.). Mason: South-Western; 2011.

13. Murray E, Rusignuolo R. Rewarding outstanding performance; Don't break the bank. In FH Maidment (21st ed.), Annual editions: Human resources 12/13. New York: McGraw-Hill Companies; 2012:80.

14. Prado-Román C, Blanco-González A, Díez-Martín F. Exploring the links between goal-setting, satisfaction and corporate culture in exhibitors at international art shows. European J. of Intl Mgmt. 2013;7(3):278-94. doi:10.1504/EJIM.2013.054326.

15. Mohammadi SM, Mohammadi SF, Hedges JR. Conceptualizing a quality plan for healthcare: A philosophical reflection on the relevance of the health profession to society. Health Care Analysis. 2007;15(4):337-61. doi: 10.1007/s10728-007-0071-7.

16. Allen N, Meyer JP. The measurement and antecedents of affective, continuance, and normative commitment to the organization. J Occup Psychology. 1990;63(1):1-8.

17. Spector P. Measurement of human service staff satisfaction: development of the job satisfaction survey. Am J Comm Psychology. 1985;13(6):693-713.

18. Rosta J, Nylenna M, Aasland OG. Job satisfaction among hospital doctors in Norway and Germany. A comparative study on national samples. Scan J Public Health 2009;37(5): 503-508.

19. Hair J, Anderson R, Tatham R, Black W. Multivariate data analysis (5th ed.). New Jersey: Prentice Hall; 1998.

20. Torp S, Grimsmo A, Hagen S, Duran A, Gudbergsson SB. Work engagement: A practical measure for workplace health promotion? Health Promotion Int. 2013;28(3):387-396. doi:10.1093/heapro/das022.

21. Lawson KJ, Noblet AJ, Rodwell J. Promoting employee wellbeing: The relevance of work characteristics and organizational justice. Health Promotion Int. 2009;24(3):223-33.

22. Blossom Y, Yung-Kai L, Cheng-Chieh L, Tien-Tse L. Job autonomy, its predispositions and its relation to work outcomes in community health centers in Taiwan. Health Promotion Int. 2013;28(2):166-77. doi:10.1093/heapro/daro91.

23. Mao H, Hsieh A. Perceived job insecurity and workplace friendship. European J of Intl Mgmt. 2013;7(6):646-70. https://doi. org/10.1504/EJIM.2013.057113.

24. Top M, Akdere M, Tarcan M. Transformational leadership, job satisfaction, organizational commitment, organizational trust in Turkish public hospitals: Public servants versus private sector employees. Int J Human Res Mgmt.. (2015); 26(9):1259-1282.

25. Akdere M. A multi-level examination of quality-focused human resource practices and firm performance: Evidence from the US healthcare industry. Intl J Human Res Mgmt. 2009; 20(9):1945-64. 
26. Akdere M, Gider O, Top M. Examining the role of employee focus in the Turkish healthcare industry. Total Quality Management and Business Excellence. 2012;23(8):1-16.

27. Bakan I, Buyukbese T, Ersahan B. The impact of total quality service (TQS) on healthcare and patient satisfaction: An empirical study of Turkish private and public hospitals. Int J Health Plan and Mgmt. 2014;29(3):292-315.

28. Eriksson A, Jansson B, Haglund BJA, Axelsson R. Leadership, organization and health at work: A case study of a Swedish industrial company. Health Promotion Intl. 2008; 23(2):127-33.

29. Polit DF, Beck CT. Nursing research: Principles and methods (7th ed.). Philadelphia, PA: Lippincott; 2004.

30. Bakan I, Buyukbese T, Ersahan B. The impact of total quality service (TQS) on healthcare and patient satisfaction: An empirical study of Turkish private and public hospitals. The Intl J. of Health Planning and Mgmt. 2014; 29(3):292-315.

31. Miller VN. When push comes to shove: A comparative concept analysis of motivation and coercion in nursing education. Nursing Forum. (2016); 51(3); 164-172.46

32. van Knippenberg B, van Knippenberg D, De Cremer D. Why people resort to coercion: The role of utility and legitimacy. European Journal of Social Psychology. (2007); 37(2): 276-287.

33. Bozaykut T, Gurbuz FG. Power and trust in organizational relations: An empirical study in Turkish public hospitals. The Intl J of Health Planning and Mgmt. 2015; 30(1): E1-E15.

34. Marchal B, Kegels G. Focusing on the software of managing health workers: What can we learn from high commitment management practices? Intl J of Health Planning and Mgmt. 2008; 23(4):299-311. 